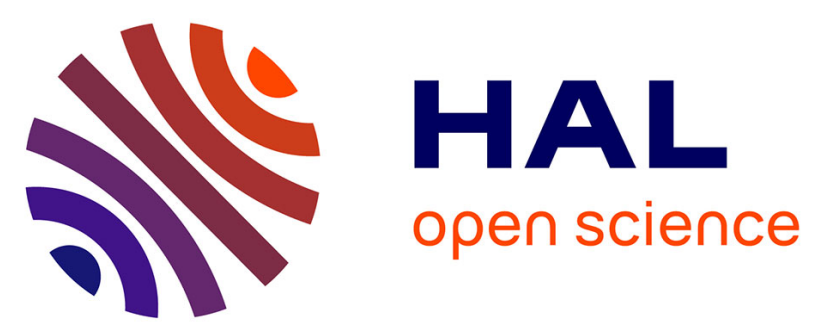

\title{
Structural characterization of hexoses and pentoses using lead cationization. An electrospray ionization and tandem mass spectrometric study \\ Jean-Yves Salpin, Jeanine Tortajada
}

\section{- To cite this version:}

Jean-Yves Salpin, Jeanine Tortajada. Structural characterization of hexoses and pentoses using lead cationization. An electrospray ionization and tandem mass spectrometric study. Journal of Mass Spectrometry, 2002, 37 (4), pp.379-388. 10.1002/jms.289 . hal-00068558

\section{HAL Id: hal-00068558 \\ https://hal.science/hal-00068558}

Submitted on 5 Oct 2018

HAL is a multi-disciplinary open access archive for the deposit and dissemination of scientific research documents, whether they are published or not. The documents may come from teaching and research institutions in France or abroad, or from public or private research centers.
L'archive ouverte pluridisciplinaire HAL, est destinée au dépôt et à la diffusion de documents scientifiques de niveau recherche, publiés ou non, émanant des établissements d'enseignement et de recherche français ou étrangers, des laboratoires publics ou privés. 


\title{
Structural characterization of hexoses and pentoses using Lead cationization. An Electrospray ionization and tandem mass spectrometry study
}

\author{
Jean-Yves Salpin and Jeanine Tortajada \\ Laboratoire Analyse et Environnement, UMR 8587, Bâtiment des Sciences; Université Evry \\ Val d'Essonne, Boulevard François Mitterrand, 91025 EVRY CEDEX, France.
}

Corresponding author: Jean-Yves Salpin

Tel: 33169477647 Fax: 33169477655

e-mail : Jean-Yves.Salpin@,chimie.univ-evry.fr

Number of pages (including Table and Figure legends) : 21

\section{Abstract}

The analytical potential of the complexation of isomeric underivatized hexoses (D-glucose, Dgalactose, D-mannose, D-talose, D-fructose), methyl-glycosides (1-O-methyl- $\alpha$-D-glucose and 1O-methyl- $\beta$-D-glucose) and pentoses (D-ribose, D-xylose, D-arabinose and $\mathrm{D}$-lyxose) by $\mathrm{Pb}^{2+}$ ions, has been investigated by electrospray ionization and tandem mass spectrometry. Lead(II) ions react mainly with monosaccharides by proton abstraction to generate $\left[\mathrm{Pb}(\text { monosaccharide })_{\mathrm{m}}-\right.$ $\mathrm{H}]^{+}$ions $(\mathrm{m}=1-3)$. At low cone voltage, a less intense series of doubly charged ions of general formula $\left[\mathrm{Pb}(\text { monosaccharide })_{\mathrm{n}}\right]^{2+}$ is also observed. The maximum number $\mathrm{n}$ of monosaccharides surrounding a single $\mathrm{Pb}^{2+}$ ion depends on the metal/monosaccharide ratio. Our study shows that MS/MS experiments have to be performed to differentiate $\mathrm{Pb}^{2+}$-coordinated monosaccharides. Upon collision, $[\mathrm{Pb}$ (monosaccharide $)-\mathrm{H}]^{+}$species mainly dissociate according to cross-ring cleavages, leading to the elimination of $\mathrm{C}_{\mathrm{n}} \mathrm{H}_{2 n} \mathrm{O}_{\mathrm{n}}$ neutrals. The various fragmentation processes observed allow the $\mathrm{C}(1), \mathrm{C}(2)$ and $\mathrm{C}(4)$ stereocenters of aldohexoses to be characterized, as well as a clear-cut aldoses/fructose distinction. Furthermore, careful analysis of MS/MS spectra also leads to successful aldopentose distinction. Lead cationization combined with tandem mass spectrometry therefore appears particularly useful to identify underivatized monosaccharides.

KEYWORDS: Mass spectrometry, Electrospray ionization, $\mathrm{Pb}^{2+}$-cationization, monosaccharides, MS/MS experiments. 


\section{INTRODUCTION}

Carbohydrates are the most abundant biomolecules in nature. They are mainly found as polysaccharides that play a crucial role in both animal and vegetal life. Cellulose for example, is a structural component of vegetal cell walls, whereas starch or glycogen constitute food storage materials. ${ }^{1}$ These three polysaccharides are homopolymers of D-glucose units bound together by different types of glycosidic linkages. The nature of the glycosidic bonds then influences both the structure and the role of these macromolecules, showing the fantastic diversity of carbohydrate chemistry.

Monosaccharides not only bind together to form polysaccharides, but also with purines and pyrimidines (ribose and 2-deoxy-ribose) to give nucleosides, and subsequently RNA and DNA. Moreover, most of naturally occurring proteins and lipids are glycosylated. Carbohydrates are thus involved in many biological functions, such as cell-cell recognition, cell-cell adhesion, and act also as antigens and as blood group substances. ${ }^{1}$

Such a variety makes oligosaccharide analysis a challenging task for mass spectrometry. A complete structural description of carbohydrates implies notably exact mass measurement, sites and anomeric configuration of the glycosidic linkages, and also stereochemical characterization of the different asymmetric centers of the sugar ring. Many studies have been carried out on those topics for more than three decades, using different ionization techniques. For many years, derivatization (methylation, permethylation and peracetylation) in conjunction with electron impact or positive ion chemical ionization have been the primary method used. ${ }^{2}$ Analysis of underivatized oligosaccharides have been also performed by negative ion chemical ionization ${ }^{3,4}$ and Field Desorption (FD), one of the earliest "soft" ionization technique. ${ }^{5,6}$ Fast Atom Bombardment (FAB) combined with MS/MS experiments has been widely applied, notably for linkage dertermination of carbohydrates, on both derivatized (positive mode) or underivatized (mainly negative mode) compounds. ${ }^{7,8}$ Other papers also mentioned the use of Laser Desorption (LD) $)^{9,10,11}$, Liquid Secondary Ion Mass Spectrometry (LSIMS) ${ }^{2,12,13}$, Matrix 
Assisted Laser Desorption Ionization mass spectrometry (MALDI). ${ }^{14,15,16}$ More recently, electrospray ionization (ESI) has been also used successfully to characterize isomeric disaccharides $^{17,18}$ and to analyse bigger glycoconjugates. ${ }^{19,20}$

With the advent of soft ionization techniques, it has been shown that structural isomers can be differentiated when coordinated to certain metal ions. Linkage positions of monosaccharide units within di- or polysaccharides have been determined by using alkali $^{21,22,23,24}$, alkaline earth ${ }^{25,26}$ and transition metal ions. ${ }^{26,27}$ Metallic species have been also involved in order to characterize the various stereocenters of the pyranose ring of aldoses. Indeed, chemical derivatization of aldoses with polyamines, combined with transition metal cationization has been examined by Leary et al. with FAB and electrospray, and lead to an unambiguous characterization of the $C(2)$ and $C(4)$ stereocenters of hexoses $28,29,30,31,32$, hexosamines ${ }^{33,34}$ and acetylhexosamines. ${ }^{34,35}$ Berjeaud et al. ${ }^{36}$ have shown that $\alpha$ and $\beta$ anomers of underivatized 1-O-Methyl-D-glucose can also be differentiated by silver cationization under FAB conditions. Finally, under ESI/MS/MS conditions, reactions of $\mathrm{FeCl}^{+}$ ions also allows unmodified aldohexoses stereoisomers to be distinguished. ${ }^{37}$

Recently, as part of our study concerning the speciation of $\mathrm{Pb}^{2+}$ ions by natural polyfunctional molecules, we investigated the intrinsic reactivity of $\mathrm{Pb}^{2+}$ ions towards several monosaccharides. ${ }^{38,39}$ It turned out that under $\mathrm{FAB}$ conditions, $\mathrm{Pb}^{2+}$ ions react with underivatized D-glucose, D-galactose and $\alpha$ and $\beta$ anomers of 1-O-Methyl-D-glucose to form intense $[\mathrm{Pb} \text { (monosaccharide) }-\mathrm{H}]^{+}$complexes. Furthermore, each of these complexes displayed a specific dissociation pattern, thus allowing the $\mathrm{C}(4)$ and anomeric centers to be characterized. These results therefore emphasized the analytical potential of lead cationization and the present paper aims to explore this potential by electrospray ionization combined with MS/MS experiments. For this purpose, we have chosen eleven D-monosaccharides, presented in scheme 1 in their pyranosic form, according to the Haworth formalism. First, we have considered seven hexoses: the four most abundant aldoses, namely D-glucose (1), D-galactose (2), D-mannose 
(3), D-talose (4), one ketose, D-fructose (5), and methyl-glycosides $\alpha$-1-O-methyl-D-glucose $(6 \boldsymbol{\alpha})$ and $\beta$-1-O-methyl-D-glucose $(\mathbf{6} \beta)$. We have also studied the reactivity of the four Daldopentoses: ribose (7), arabinose (8), xylose (9) and lyxose (10). Experiments have been carried out without any preliminary monosaccharide derivatization.

$<$ Scheme $1>$

\section{EXPERIMENTAL}

Electrospray mass spectra were recorded on an Applied Biosystems/MDS Sciex API2000 triple-quadrupole instrument fitted with a "turboionspray" ion source. Samples were introduced in the source using direct infusion with a syringe pump at a flow rate of $5 \mu \mathrm{l} / \mathrm{min}$. Ionization of the samples was achieved by applying a voltage of $5.5 \mathrm{kV}$ on the sprayer probe and by the use of a nebulizing gas (GAS1, $\mathrm{N}_{2}$ ) surrounding the sprayer probe, intersected by a heated gas $\left(\mathrm{GAS} 2, \mathrm{~N}_{2}\right)$ at an angle of approximately $90^{\circ}$. The operating pressure of these two gases were typically 1.4 and 2.1 bars, respectively, and the temperature of GAS2 was set at $100^{\circ} \mathrm{C}$. The curtain gas $\left(\mathrm{N}_{2}\right)$, which prevents air or solvent from entering the analyser region, was adjusted at a pressure of 2.1 bars. As detailed in the following sections, the declustering potential (DP), defined as the difference of potentials between the orifice plate and the skimmer, was fixed to 20 volts to record both MS and MS/MS experiments. Low-energy collision induced dissociation (CID) spectra were carried out by introducing nitrogen as collision gas in the second quadrupole, at a total pressure of $410^{-5}$ mbars, the background pressure being around $10^{-5}$ mbars.

Since our laboratory is interested in the speciation of $\mathrm{Pb}^{2+}$ ions in natural media, and more particularly in water, all the measurements presented thereafter were carried out in $100 \%$ of water purified with a Milli-Q water purification system. Nevertheless, we made several experiments with a 50/50 (v:v) water/methanol mixture and we also observed intense 
lead/sugar complexes. However, spectra are more complicated because of additional complexation processes between lead and one or several molecules of methanol. Fortunately, these processes do not alter the mass region of the lead/monosaccharide complex chosen for fragmentation. Moreover, MS/MS experiments have shown that CID spectra of those complexes are not solvent-dependent. It is therefore possible to carry out this study in a water/methanol mixture without using the heated drying gas.

Lead nitrate was chosen to generate $\mathrm{Pb}^{2+}$ ions because of its high solubility in water. All the monosaccharides were dissolved in water without any preliminary derivatization. Note that except for 1-O-methyl- $\alpha$-D-glucose $(\mathbf{6} \boldsymbol{\alpha})$ and 1-O-methyl- $\beta$-D-glucose $(\mathbf{6} \beta)$, solubilization in water results in the loss of stereochemistry of the anomeric center. As detailed in the next section several metal:sugar ratios have been tested and we opted for a 1:2 ratio, with concentrations of $510^{-5} \mathrm{~mol} / \mathrm{L}$ and $10^{-4} \mathrm{~mol} / \mathrm{L}$, respectively.

Metallic salt and monosaccharides are commercially available from Aldrich and Fluka and were used without any further purification.

\section{RESULTS AND DISCUSSION}

\section{Positive ion electrospray spectra of cationized monosaccharides}

Lead has four natural isotopes with the following repartition: $1.4 \%{ }^{204} \mathrm{~Pb} / 24.1 \%{ }^{206} \mathrm{~Pb} /$ $22.1 \%{ }^{207} \mathrm{~Pb} / 52.4 \%{ }^{208} \mathrm{~Pb}$. Because of this specific isotopic distribution, peaks involving one lead atom should correspond to characteristic triplets on the spectra and should be easily identified (to simplify, we won't consider the very weak ${ }^{204} \mathrm{~Pb}$ contribution). Unless otherwise noted, the results presented thereafter will refer to ions involving the most abundant isotope, namely ${ }^{208} \mathrm{~Pb}$.

Figure 1 presents the $\mathrm{m} / \mathrm{z} 200-800$ range of the electrospray spectrum obtained at a declustering potential of 20 volts, when introducing an aqueous lead nitrate/D-fructose mixture $\left(510^{-5}\right.$ 
mol. $\left.\mathrm{L}^{-1} / 10^{-4} \mathrm{~mol} \cdot \mathrm{L}^{-1}\right)$. As expected, peaks involving one lead atom are easily recognizable. First, we can see a series of characteristic triplets due to reaction between $\mathrm{Pb}^{2+}$ ions and water: $\mathrm{m} / \mathrm{z} 225,243,261,279,297$, and 315 , that we assigned to $\mathrm{PbOH}^{+}, \mathrm{PbOH}^{+} . \mathrm{H}_{2} \mathrm{O}, \mathrm{PbOH}^{+} .2 \mathrm{H}_{2} \mathrm{O}$, $\mathrm{PbOH}^{+} .3 \mathrm{H}_{2} \mathrm{O}, \mathrm{PbOH}^{+} .4 \mathrm{H}_{2} \mathrm{O}$ and $\mathrm{PbOH}^{+} .5 \mathrm{H}_{2} \mathrm{O}$ respectively, as confirmed by low-energy CID spectra. Increasing the declustering potential from 0 to 200 volts results in gradual removal of ions $\mathrm{m} / \mathrm{z} 243,261,279,297$ and 315, thus confirming their solvated structure. Conversely, bare lead ion $\mathrm{Pb}^{+}(\mathrm{m} / \mathrm{z} 208)$ starts to appear from $\mathrm{DP}=50$ volts, to become the base peak at $\mathrm{DP}=200$ volts.

Secondly, numerous ions arise from the interaction between lead(II) ions and the monosaccharide, and the same trend is observed for all the compounds. For all the eleven carbohydrates considered, two distinct series of complexes are observed. First, $\mathrm{Pb}^{2+}$ ions react with the sugar by removal of an acidic proton to generate $\left[\mathrm{Pb}(\text { monosaccharide })_{\mathrm{m}}-\mathrm{H}\right]^{+}$ complexes $(\mathrm{m}=1-3)($ marked out by black arrows, Figure 1$)$. For a hexose (here D-fructose), this reaction gives rise to ions at $\mathrm{m} / \mathrm{z} 387,567$ and 747 . The second series (presently $\mathrm{m} / \mathrm{z} 284,374$, 464, 554 and 664, white arrows) corresponds to doubly charged ions of general formula $\left[\mathrm{Pb}(\text { hexose })_{\mathrm{n}}\right]^{2+}(\mathrm{n}=2-6)$. For the four pentoses, removal of an acidic proton gives rise to ions at $\mathrm{m} / \mathrm{z} 357,507$ and $657(\mathrm{~m}=1-3)$, and doubly charged ions $[\mathrm{Pb}(\text { pentose }) \mathrm{n}]^{2+}(\mathrm{n}=2-5)$ are also detected (m/z 254, 329, 404, 479) but to a lesser extent. This double reactivity has been already observed for alkaline earth cations in presence of trisaccharides. ${ }^{40}$ Finally, note that we don't observe ions involving both cationized-sugar and nitrate counter-ion.

To optimize the ion yield formed by the electrospray process, we first studied the metal:monosaccharide ratio. This was achieved by varying the concentration of the metal while keeping that of D-glucose constant $\left(10^{-4} \mathrm{~mol} / \mathrm{L}\right)$, the DP value being fixed at 20 volts. At a 1:1 ratio, the proportion of doubly charged ion appeared very weak compared to that of $[\mathrm{Pb}(\mathrm{D}-$ glucose $\left.)_{n}-\mathrm{H}\right]^{+}$complexes. For a lead to monosaccharide ratio of $1: 2$, the overall abundance of singly charged ions remains generally unchanged while we observe significative amount of 
$[\mathrm{Pb}(\text { monosaccharide }) \mathrm{n}]^{2+}$ species (see Figure 1$)$. At a ratio 1:5, singly charged complexes are less intense but still more abundant than their doubly charged counterparts. An interesting feature is that the number of glucose units around $\mathrm{Pb}^{2+}$ ions increases while decreasing the proportion of the metal, and for the stoichiometry 1:10 we observed a series of eleven $[\mathrm{Pb}(\mathrm{D}-$ glucose $\left.)_{n}\right]^{2+}$ ions $(n=2-12)$. Characterizing the structure of these doubly charged species is beyond the scope of the present paper. However, given the fact that the maximum number of glucose units can be more important than the maximum coordination number of lead(II) ions, one may reasonably assume that these species could correspond $\mathrm{Pb}^{2+}$ ions actually chelated by few glucose units ( 1 to 3 , inner coordination sphere), and surrounded by the other glucoses via intermolecular hydrogen bonds (outer coordination sphere). In conclusion, the metal:monosaccharide ratio influences the relative abundance of these two series, but the effect is not as spectacular as for $\mathrm{Ca}^{2+}$ ions. ${ }^{40}$ Whatever the ratio considered, $\left[\mathrm{Pb}(\text { monosaccharide })_{\mathrm{m}}-\right.$ $\mathrm{H}]^{+}$ions are predominant and $\mathrm{m} / \mathrm{z} 387$ is always the most intense complex observed. The highest ionization yield is obtained for the ratio 1:2.

We have also carried out a declustering potential optimization by ramping its value from 0 to 200 volts. Our results show that whatever the metal:monosaccharide ratio considered, intact metal/glycosides complexes are particularly abundant at low DP values. Maximization of both singly charged and doubly charged complexes occurred at a DP of 20 Volts. Their intensity then dropped quickly above 30 volts. Indeed, raising the DP value induces dissociation of the different organometallic complexes. We checked if those "in-source" fragmentations could be helpful for isomeric distinction. Unfortunately, isobaric aldoses (either pentoses, hexoses or methyl hexoses) gave similar dissociations and therefore can't be characterized. This has been already observed by different groups who used either alkaline, alkaline earth or transition metals as ionizing reactants. The only interesting feature is that D-fructose (5) can be distinguished from aldoses at this step, the fragment ion at $\mathrm{m} / \mathrm{z} 327$ being absent for the ketose. 
In summary, these results demonstrate that MS/MS experiments are necessary to differentiate the various isomers. For this purpose, we chose the $[\mathrm{Pb} \text { (monosaccharide) }-\mathrm{H}]^{+}$species since it is the most intense organometallic complex detected for all the monosaccharides. From the previous optimization steps, a 1:2 metal:monosaccharide ratio and a DP value of 20 volts were retained for MS/MS experiments. The results are presented in the next section.

In conclusion, the electrospray spectrum of the aqueous solution of lead nitrate is rather easy to interpret, and is much more simple than the spectrum obtained under FAB conditions, which shows above $\mathrm{m} / \mathrm{z} 400$, many species due to gas-phase reactions between lead and glycerol, and containing one, two or three lead atoms. ${ }^{38}$

\section{Low-energy CID spectra of cationized hexoses and methyl-hexoses}

The different $\left([\mathrm{Pb} \text { (hexose) }-\mathrm{H}]^{+}\right.$species involving ${ }^{208} \mathrm{~Pb}(\mathrm{~m} / \mathrm{z} 387)$ were selected and allowed to dissociate upon collision with nitrogen. For the sake of comparison, all the MS/MS spectra presented thereafter were recorded with strictly the same experimental conditions (gases, potentials), except for the collision energy, optimized for each compound so as to adjust the remaining intensity of the parent ion to c.a. $25 \%$.

The results of the MS/MS experiments for the hexoses are summarized in Table 1 and are illustrated by the Figure 2. These experiments show that $[\mathrm{Pb}(\text { hexose })-\mathrm{H}]^{+}$ions fragment essentially according to cross ring cleavages, characterized by elimination of $\mathrm{C}_{\mathrm{n}} \mathrm{H}_{2 \mathrm{n}} \mathrm{O}_{\mathrm{n}}$ molecules $(n=2-4)$, and leading to 327, 297 and 267 ions. These dissociation processes have been already observed both under FAB and electrospray conditions for hexoses cationized by various divalent ions such as $\mathrm{Ni}(\mathrm{II})^{28,31}, \mathrm{Zn}(\mathrm{II})^{30,31}, \mathrm{Cu}(\mathrm{II})^{31}, \mathrm{Co}(\mathrm{II})^{32}$ and $\mathrm{Fe}(\mathrm{II}) .{ }^{37}$ Precursor ion scan spectra and neutral loss experiments have shown that formation of 297 and 267 ions correspond essentially to primary fragmentations, elimination of formaldehyde from $\mathrm{m} / \mathrm{z} 327$ 
and 297, respectively, being minor processes. Furthermore, m/z 267 ions arise either directly from the parent ion or via the intermediate formation of $\mathrm{m} / \mathrm{z} 327$ ions.

The reactivity of $\mathrm{Pb}(\mathrm{II})$ ions also induces particular dissociation processes, attributed to formal simultaneous elimination of $\mathrm{H}_{2} \mathrm{O}$ and $\mathrm{C}_{\mathrm{n}} \mathrm{H}_{2 \mathrm{n}} \mathrm{O}_{\mathrm{n}}(\mathrm{n}=2,3)$ neutrals, giving rise to ions at $\mathrm{m} / \mathrm{z} 309$ and 279. In fact, our experiments suggest that these two fragment ions are not only generated directly from $\mathrm{m} / \mathrm{z} 387$, but also via an intermediate formation of $\mathrm{m} / \mathrm{z} 327$ and 297 ions, respectively. These particular dissociation processes have been observed before only in the case of copper cationization combined with use of ethylenediamine. ${ }^{31}$

Table 1 also indicates that dehydration from $[\mathrm{Pb}(\text { hexose })-\mathrm{H}]^{+}$is a minor process, whereas it is the main reaction observed when Fe(II) ions react with underivatized aldoses. ${ }^{37}$ Moreover, CID spectra don't exhibit m/z 351 ions, which would correspond to loss of two molecules of water. Finally, we don't detect any neutral fragments retaining the metal.

In summary, careful examination of the literature underlines the diversity in both the nature and the competition of the dissociation processes of cationized hexoses. This may be due to the intrinsic reactivity of the metal since the coordination sites and the activated bonds may vary with the metal. Nevertheless, energetic factors have also to be taken into account. For instance, $[\mathrm{Pb}(\text { glucose })-\mathrm{H}]^{+}$ions generated by $\mathrm{FAB}$ and undergoing metastable decomposition in the second field free region of a sector instrument ${ }^{38}$, have a narrow internal energy distribution and dissociate according to few fragmentation processes (loss of water and $\mathrm{C}_{2} \mathrm{H}_{4} \mathrm{O}_{2}$ ), of low critical energy and low abundance. The metastable spectrum is, as expected, different from the electrospray low-energy CID spectrum presented in Figure 2, due to difference in the internal energy distribution of precursor ions prior to dissociation. One can't also exclude the possibility that two distinct ionization methods may lead to $[\mathrm{Pb}(\text { hexose })-\mathrm{H}]^{+}$ions having different structures. It must be also noticed that until now, most of the electrospray studies dealing with the stereochemical characterization of hexoses, have been carried out with quadrupole ion trap devices. MS/MS spectra obtained with such instruments are hardly comparable with those 
recorded with our triple-quadrupole mass spectrometer for several reasons. The first one is that different activation methods are employed. Resonance excitation in ion trap instruments can be as long as hundreds of milliseconds (slow process) whereas the residence time of an ion in a collision cell of a triple-quadrupole instrument is about tenths of microseconds (fast process). 41,42 This can result in different internal energy distribution and consequently to different dissociation behavior of the precursor ions. Another reason is that the appearance of the MS/MS spectrum is partly determined by constraints imposed by the instrument itself, such as time frames, geometry of the electrospray source, collection efficiencies or detector response.

The CID spectra for the five $[\mathrm{Pb}(\text { hexose })-\mathrm{H}]^{+}$ions were obtained with a center of mass collision energies $\left(E_{\text {com }}\right)$ ranging from 0.9 to $1.8 \mathrm{eV}$. The data summarized in Table 1 show that each $[\mathrm{Pb}(\text { hexose })-\mathrm{H}]^{+}$species exhibits a specific fragmentation pattern. Glucose (1) is distinguished from its isomers by the lack of any water loss from the precursor ion. The ion $\mathrm{m} / \mathrm{z} 327$ ion is the base peak of the CID spectrum of glucose (1) and mannose (3), whereas $\mathrm{m} / \mathrm{z} 267$ is predominent for galactose (2) and talose (4). The differentiation between galactose (2) and mannose (3), as well as between mannose (3) and talose (4) is therefore easily achieved. If one assumes that the various aldoses retain their energetically preferred ${ }^{4} \mathrm{C}_{1}$ chair pyranosyl conformation $^{43}$ during the interaction with the metallic center and the desolvation-ionization process, the loss of 120 mass units (elimination of $\mathrm{C}_{4} \mathrm{H}_{8} \mathrm{O}_{4}$ ) is favored when the $\mathrm{C}(4)$ hydroxyl group is in the axial position (Scheme 1). This particular configuration also tends to enhance the formation of $\mathrm{m} / \mathrm{z} 297$, as already observed under FAB conditions for D-glucose and Dgalactose. ${ }^{38}$ Conversely, the position of the hydroxyl on the $C(2)$ stereocenter does not seem to influence any dissociation process, as illustrated by the comparison between the product ion spectra obtained for galactose and talose (Table 1, Figure 2). However, even if these spectra, at a first glance, are rather similar, they may be useful for analytical purpose, by considering the abundance ratios $327 / 267$ and $297 / 279$. Thus, efforts were made to check whether the differences in the relative ion intensities were reproducible and large enough to reliably 
differentiate the two epimers. To this end, we recorded for each of the five hexoses, a series of six distinct product ion spectra. The standard deviations obtained are given in Table 1. We can see that they are systematically less than $3 \%$ of the most intense product ion for a given spectrum. Consequently, these variations are smaller than the differences in relative product ion intensities. So, product ion spectra of the $\mathrm{m} / \mathrm{z} 387$ precursor ion appear sufficiently reproducible to use confidently the abundance ratios 327/267 and 297/279 for galactose/talose distinction. These ratios are equal to $0.78 \pm 0.02$ and $1.3 \pm 0.05$ respectively, for the former epimer, and to $0.24 \pm 0.01$ and $0.55 \pm 0.06$ for the latter one. These values are significantly different and we can conclude that lead cationization combined with tandem mass spectrometry, allows, under electrospray conditions, galactose (2) and talose (4) to be distinguished, and more generally, the $\mathrm{C}(2)$ and $\mathrm{C}(4)$ stereocenters to be characterized.

In addition, we have also studied the most abundant ketose, namely D-fructose (5). We have seen in the previous section that fructose can be distinguished from the four isobaric aldoses by means of "in source" fragmentations. This is also the case with MS/MS experiments. Figure 2 displays the product ion spectrum of $[\mathrm{Pb}(\text { fructose })-\mathrm{H}]^{+}$ions. Their dissociation is radically different from that of aldoses 1-4. The overwhelming process is, by far, formation of $\mathrm{m} / \mathrm{z} 297$ ions (loss of $\mathrm{C}_{3} \mathrm{H}_{6} \mathrm{O}_{3}$ ). The MS/MS spectrum is also devoid of the ion $\mathrm{m} / \mathrm{z} 327$ observed with hexoses 1-4, hence a straightforward fructose/aldoses distinction, as already observed during MIKES experiments combined with FAB ionization. ${ }^{38}$

Finally, we have also studied the gas-phase reactivity of $\mathrm{Pb}^{2+}$ ions towards $\alpha-1-\mathrm{O}-$ methyl-Dglucose $(6 \alpha)$ and $\beta$-1-O-methyl-D-glucose $(6 \beta)$. Unlike the others sugars presently studied, these two compounds, when solubilized in water, retain the stereochemistry of the anomeric center C(1) (Scheme 1). Promé and co-workers have already addressed the mass spectrometric characterization of the $\mathrm{C}(1)$ stereocenter. They first studied the metastable decomposition of oxyanions $[\mathrm{M}-\mathrm{H}]^{-}$generated by fast atom bombardment ${ }^{8}$, but failed to distinguish the two 1-O- 
methyl-D-glucopyranosides. This was achieved by silver cationization and unimolecular decompositions of $[\mathrm{M}-\mathrm{Ag}]^{+}$species. $^{36}$

Based on the comparison of the CID spectra of the two $[\mathrm{Pb}(1-\mathrm{O}-\text { methyl-D-glucose })-\mathrm{H}]^{+}$ complexes, we checked if the reactivity of Lead(II) ions under electrospray conditions, could allow the C(1) stereochemistry to be characterized. These two spectra are presented in Figure 3, the residual intensity of the precursor ion ( $\mathrm{m} / \mathrm{z} 401)$ being about $25 \%$ (this was achieved with a center of mass collision energy of 1.5 and $1.6 \mathrm{eV}$ for the $\alpha$ and $\beta$ anomers, respectively). For the two compounds, the main process is the formation of the ion $\mathrm{m} / \mathrm{z} \mathrm{267}$, attributed to elimination of a $\mathrm{C}_{5} \mathrm{H}_{10} \mathrm{O}_{4}$ molecule. A loss of methanol is detected whereas dehydration was not observed with glucose. But the most striking feature is the formation of the ions $\mathrm{m} / \mathrm{z} 351$ (assigned to simultaneous loss of water and methanol) exclusively encountered for the $\alpha$ anomer, and $\mathrm{m} / \mathrm{z} 297$ (elimination of $\mathrm{C}_{4} \mathrm{H}_{8} \mathrm{O}_{3}$ ), also characteristic of this isomer. We already observed this typical behavior of $\alpha-1-\mathrm{O}-$-methyl-D-glucose during the metastable decompostion of the $[\mathrm{Pb}(\mathbf{6} \boldsymbol{\alpha})-\mathrm{H}]^{+}$ions generated by $\mathrm{FAB}^{38}$ These results suggest that the anomeric center play a crucial role in the unimolecular chemistry of $[\mathrm{Pb}(6 \boldsymbol{\alpha})-\mathrm{H}]^{+}$and $[\mathrm{Pb}(6 \boldsymbol{\beta})-\mathrm{H}]^{+}$ions, and more generally on the dissociation processes of $\mathrm{Pb}(\mathrm{II}) /$ hexose complexes. As a matter of fact, even if nothing allows assertion that glucose and methyl-D-glucoses will interact with $\mathrm{Pb}^{2+}$ ions by the same way, comparison of the MS/MS spectra provides interesting information concerning the carbon atoms eliminated during the cross ring cleavages. When a methoxyl group replaces the anomeric hydroxyl one, loss of $\mathrm{C}_{2} \mathrm{H}_{4} \mathrm{O}_{2}$ is totally changed for $\mathrm{C}_{3} \mathrm{H}_{6} \mathrm{O}_{2}$, thus pointing out that the anomeric center might be involved in the fragmentation. If so, one may reasonably assume that the second carbon atom eliminated could correspond to $\mathrm{C}(2)$, insofar elimination of $\mathrm{C}_{2} \mathrm{H}_{4} \mathrm{O}_{2}$ involving $\mathrm{C}(1)$ and not $\mathrm{C}(2)$, would require a considerable rearrangement during the dissociation. Similarly, the loss of 90 mass units is no longer observed for methyl-D-glucoses, and is shifted to 104 mass units (m/z 297), thus suggesting that the elimination of $\mathrm{C}_{3} \mathrm{H}_{6} \mathrm{O}_{3}$ neutral could involve $\mathrm{C}(1), \mathrm{C}(2)$ and $\mathrm{C}(3)$ centers. Moreover, 
observation of both $\mathrm{m} / \mathrm{z} 281$ (loss of 120 mass units) and m/z 267 (loss of 134 mass units) for $\mathbf{6} \alpha$ and $\mathbf{6} \beta$, seems to indicate that elimination of a $\mathrm{C}_{4} \mathrm{H}_{8} \mathrm{O}_{4}$ molecule might correspond to two distinct processes, elimination of a $\mathrm{C}(1)-\mathrm{C}(4)$ chain being predominent. Finally, elimination of methanol from $[\mathrm{Pb}(\mathbf{6} \boldsymbol{\alpha})-\mathrm{H}]^{+}$and $[\mathrm{Pb}(\mathbf{6} \boldsymbol{\beta})-\mathrm{H}]^{+}$ions and overwhelming formation of $\mathrm{m} / \mathrm{z} 297$ for D-fructose, support the hypothesis of the central role of the anomeric center. A complete study on the dissociation mechanisms of $[\mathrm{Pb}(\mathrm{D} \text {-glucose })-\mathrm{H}]^{+}$, involving labeled compounds and theoretical calculations, is currently under progress in order to determine the best coordination site of $\mathrm{Pb}^{2+}$ ions, and to confirm or invalidate these assumptions.

In conclusion, the present section has demonstrated that the reactivity of $\mathrm{Pb}^{2+}$ under electrospray conditions, allows the $\mathrm{C}(1), \mathrm{C}(2)$ and $\mathrm{C}(4)$ asymetric carbons of hexoses to be characterized, and a clear-cut distinction aldoses/fructose, without preliminary derivatization.

\section{Low-energy CID spectra of cationized pentoses}

Metal coordination to pentoses has been extensively studied in solution, and generally implies both structural and thermochemical characterization of the complexation process. ${ }^{44,45,46}$ Conversely, to our knowledge, the gas-phase interaction between metal ions and underivatized pentoses has been scarcely studied. Cerda et $a l .{ }^{47}$ determined absolute sodium affinities for ribose, xylose and arabinose, by means of the kinetic method ${ }^{48}$, and affirmed that this thermochemical property could be used for distinguishing stereoisomers, even in the case of energy differences as small as $1 \mathrm{~kJ} / \mathrm{mol}$. In fact, apart from this study, mass spectrometric characterization of pentoses have not involved metal ions so far, but instead several chemical ionization methods involving unusual reagents such as dialkyl acetal and thioacetals ${ }^{49}$, acetone $^{50}$, trimethyl borate ${ }^{51}$ or methylene chloride ${ }^{52}$. Field desorption ${ }^{53}$ and thermospray ${ }^{54}$ have been also used for that purpose.

The present section reports the results obtained when Lead(II) ions are used in combination with MS/MS experiments to analyse four pentoses differing from one another by the 
stereochemistry of $\mathrm{C}(2)$ and $\mathrm{C}(3)$ centers (Scheme 1$)$. Product ion spectra of $[\mathrm{Pb} \text { (pentose)-H }]^{+}$ ions are summarized in Table 2 and are illustrated by the Figure 4 . We adopted the same experimental protocole than for hexoses. The center of mass collision energies, optimized so as to obtain a remaining intensity for the precursor ion $(\mathrm{m} / \mathrm{z} 357)$ of c.a. $25 \%$, range from 1.2 to $2.0 \mathrm{eV}$. Like hexoses, $\mathrm{m} / \mathrm{z} 357$ eliminate $\mathrm{C}_{\mathrm{n}} \mathrm{H}_{2 \mathrm{n}} \mathrm{O}_{\mathrm{n}}$ molecules $(\mathrm{n}=2,3)$ by cross-ring cleavages, to generate $\mathrm{m} / \mathrm{z} 297$ and 267. On the other hand, we don't observe loss of 120 mass units. Precursor ion scan spectra and neutral loss experiments indicate that $\mathrm{m} / \mathrm{z} 267$ ions arise either directly from the parent ion or via the intermediate formation of $\mathrm{m} / \mathrm{z} 297$, which expels a formaldehyde molecule. Dehydration (m/z 339) takes place for the four isomers. A second molecule of water is lost in the particular case of $[\mathrm{Pb}(7)-\mathrm{H}]^{+}$and $[\mathrm{Pb}(\mathbf{8})-\mathrm{H}]^{+}$ions.

Characteristic simultaneous eliminations of $\mathrm{H}_{2} \mathrm{O}$ and $\mathrm{C}_{\mathrm{n}} \mathrm{H}_{2 n} \mathrm{O}_{n}$ neutrals $(n=1,2)$, giving rise to ions at m/z 309 and 279, are also encountered. Finally, like hexoses, elimination of a neutral metallic species is never observed.

From Table 2 and Figure 4, we can see that the four $\left[\mathrm{Pb}(\text { pentose) }-\mathrm{H}]^{+}\right.$ions have different MS/MS spectra. The CID spectrum obtained for D-ribose is markedly different than the three other spectra, since it presents more efficient fragmentation pathways, m/z 279 as the base peak, and two abundant daughter ions (m/z 267 and 279). Characterization of D-ribose is therefore straightforward. This particular behavior of $[\mathrm{Pb}(\text { ribose })-\mathrm{H}]^{+}$species might be correlated with the properties of the aqueous solution. Indeed, D-ribose is the only pentose studied which presents in solution a significant amount of furanosic forms ${ }^{43}$ (about $19 \%$ at $31^{\circ} \mathrm{C}$ ). Gas-phase interactions between Lead(II) ions and furanosic structures might then result in additional ways of dissociation. On the other hand, D-arabinose (8), D-xylose (9) and Dlyxose (10), as well as compounds $\mathbf{1 - 4}$, exists almost exclusively in aqueous solution in their pyranosic forms, and this might account for fewer fragment ions.

CID spectrum of $[\mathrm{Pb}(\mathbf{8})-\mathrm{H}]^{+},[\mathrm{Pb}(\mathbf{9})-\mathrm{H}]^{+}$and $[\mathrm{Pb}(\mathbf{1 0})-\mathrm{H}]^{+}$ions present several common features, namely m/z 297 as the base peak and significant amounts of m/z 339, 297 and 279 
ions. Nevertheless, these three isomers can be distinguished by considering the two peaks at $\mathrm{m} / \mathrm{z} 321\left(-2 \mathrm{H}_{2} \mathrm{O}\right)$ and $309\left(-\mathrm{CH}_{2} \mathrm{O} /-\mathrm{H}_{2} \mathrm{O}\right)$. These two ions are detected when colliding $[\mathrm{Pb}(\mathbf{8})-$ $\mathrm{H})]^{+}$species, are absent when studying D-xylose (9). Finally, the former one is not observed in the particular case of D-lyxose (10). However, given the fact that these two species are of low abundance, we checked if their intensities were reproducible enough to be used for structural differentiation. For this purpose, we recorded for all the pentoses, six distinct product ion spectra. The standard deviations associated with the differents peaks are given in Table 2. As already noticed for hexoses, the reproducibility is good, less than $2.5 \%$ for the most intense fragment. Consequently, these two peaks can be used confidently. Furthermore, these three isomers may also be distinguished from $\mathrm{m} / \mathrm{z} 267$ ions. This fragment ion is particularly important for $[\mathrm{Pb}(9)-\mathrm{H})]^{+}(76 \%)$, but also for $\left.[\mathrm{Pb}(7)-\mathrm{H})\right]^{+}$. This suggests that the elimination of $\mathrm{C}_{3} \mathrm{H}_{6} \mathrm{O}_{3}$ from coordinated pyranosic pentoses is favored when the $\mathrm{C}(2)$ hydroxyl group (Scheme 1) is in the equatorial position. Furthermore, from these series of experiments, we may deduce an abundance ratio $279 / 267$ of $0.80 \pm 0.06$ and $0.39 \pm 0.01$ for $[\mathrm{Pb}(\mathbf{8})-\mathrm{H})]^{+}$and $[\mathrm{Pb}(\mathbf{1 0})$ $\mathrm{H})]^{+}$ions, respectively, which allows these two epimers to be distinguished. In summary, the fragmentations observed on product ion spectra allow unambiguous distinction of the four pentoses studied, and in other terms the $C(2)$ and $C(3)$ stereocenters of aldopentoses to be characterized.

\section{Conclusion}

The present study has demonstrated that diasteromeric hexoses and pentoses can be distinguished using Lead cationization and electrospray/triple-quadrupole mass spectrometry, without any preliminary derivatization. Moreover, experiments carried out on 1-O-methyl-Dglucoses have demonstrated that the sterochemistry of the anomeric center can be easily 
determined. Detail studies involving labelled compounds and molecular orbital calculations are currently in progress in the particular case of D-glucose and D-ribose, so as to suggest possible mechanisms of dissociation of the $[\mathrm{Pb}$ (monosaccharide) $-\mathrm{H}]+$ complexes, as well as the preferred coordination sites for $\mathrm{Pb}^{2+}$ ions.

\section{Table and Figure caption}

Table 1. Abundance (\%) of the main fragment ions in the CID spectra of the $[\mathrm{Pb} \text { (hexose) }-\mathrm{H}]^{+}$ ions $(\mathrm{m} / \mathrm{z} 387)$ of $1-5^{a}$.

Table 2. Abundance (\%) of the main fragment ions in the CID spectra of the $[\mathrm{Pb}+\text { pentose- } \mathrm{H}]^{+}$ ions $(\mathrm{m} / \mathrm{z} 357)$ of $7-10^{\mathrm{a}}$.

Figure 1. m/z 200-800 range of the positive-ion electrospray mass spectrum of an aqueous $\mathrm{Pb}\left(\mathrm{NO}_{3}\right)_{2} / \mathrm{D}$-fructose $\left(510^{-5} \mathrm{~mol} . \mathrm{L}^{-1} / 10^{-4} \mathrm{~mol} . \mathrm{L}^{-1}\right)$ solution.

Figure 2. Low-energy CID spectra of $[\mathrm{Pb} \text { (hexose) }-\mathrm{H}]^{+}$ions (m/z 387).

Figure 3. Low-energy CID spectra of [Pb(1-methyl-D-glucose) - $\mathrm{H}]^{+}$ions (m/z 401).

Figure 4. Low-energy $\mathrm{CID}$ spectra of $[\mathrm{Pb} \text { (pentose) - } \mathrm{H}]^{+}$ions (m/z 357). 

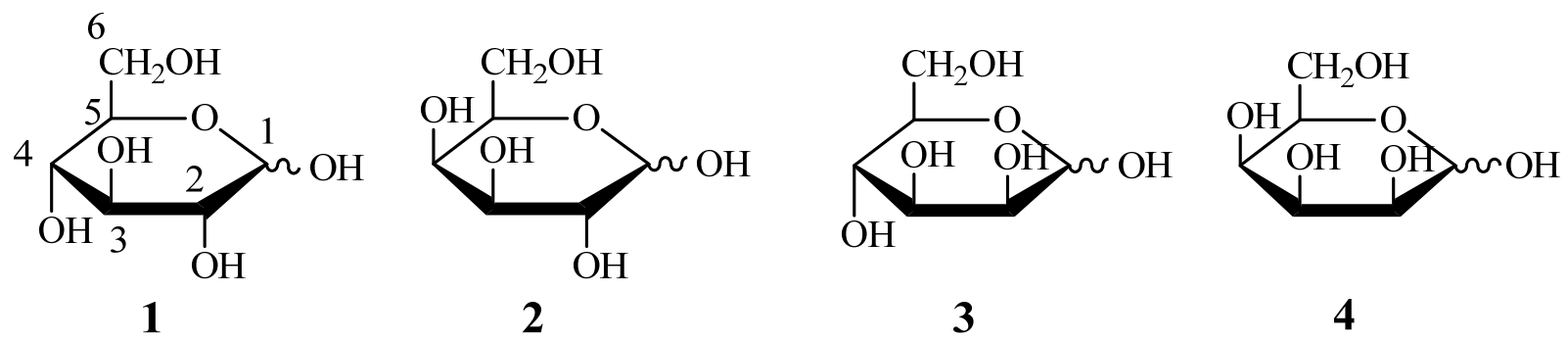

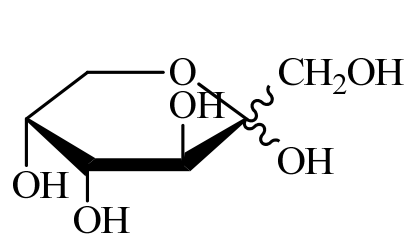

5

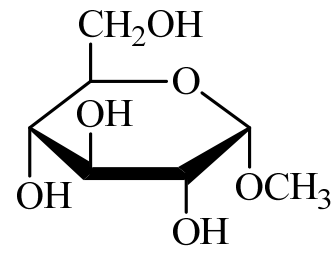

$6 \alpha$

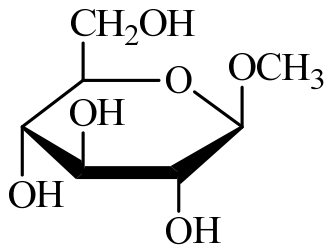

$6 \beta$

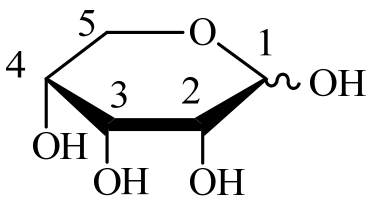

7

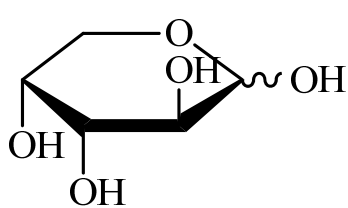

8

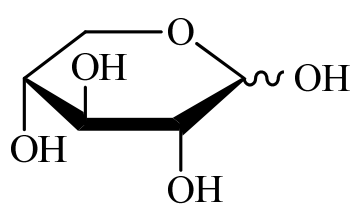

9

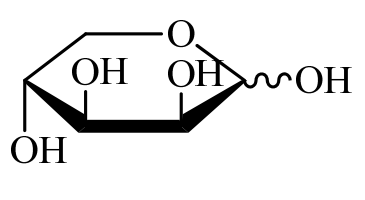

10

Scheme 1 


\section{References}

1. Lehninger AL, Nelson DL, Cox MM In Principes de biochimie ( $2^{\text {nd }}$ ed). Flammarion: Paris; 1994.

2. Reinhold VN, Carr SA. Mass Spectrometry Reviews. 1983; 2: 153.

3. Cole RB, Tabet JC, Salles C, Jallageas JC, Crouzet J. Rapid Communications in Mass Spectrometry. 1989; 3; 59.

4. Ma LB, Fournier F, Blasco T, Tabet JC, Salles C, Jallegeas, JC. Journal of the American Society for Mass Spectrometry. 1992; 3: 232.

5. Beckey HD. International Journal of Mass Spectrometry and Ion Physics. 1969; 2: 500.

6. Schulten HR. International Journal of Mass Spectrometry and Ion Physics. 1979; 32: 97.

7. Hegge H, Peter-Katalinić J. Mass Spectrometry Reviews. 1987; 6: 331.

8. Promé JC, Aurelle, H, Promé D, Savagnac A. Organic Mass Spectrometry. 1987; 22: 6.

9. Vastola FJ, Pirone AJ. Advances in Mass Spectrometry. 1968; 4: 107.

10. Coates ML, Wilkins CL. Analytical Chemistry. 1987; 59: 197.

11. Spengler B, Dolce JW, Cotter RJ. Analytical Chemistry. 1990; 62: 1731.

12. Kambara H, Hishida S. Analytical Chemistry.1981; 53: 2340.

13. Zapfe, S, Müller D. Rapid Communications in Mass Spectrometry. 1998; 12: 545.

14. Stahl B, Steup M, Karas M. Hillenkamp F. Analytical Chemistry. 1991; 63: 1463.

15. Spengler B, Kirsch D, Kaufmann R, Lemoine J. Journal of Mass Spectrometry. 1994; 29: 782.

16. Perreault H, Costello CE. Journal of Mass Spectrometry. 1999; 34: 184. 
17. Garozzo D, Impallomeni G, Spina E, Green BN, Hutton T. Carbohydrate Research. 1991; 221: 253 .

18. Mulroney B, Traeger JC, Stone BA. Journal of Mass Spectrometry. 1995, 30: 1277.

19. Ohashi Y in Electrospray Ionisation Mass Spectrometry: Fundamentals, Instrumentation and Applications. Cole RB (ed). John Wiley and Sons: Chichester; page 459, 1997.

20. Chai W, Piskarev V, Lawson AM. Analytical Chemistry. 2001; 73: 651.

21. Zhou Z, Ogden S , Leary JA. Journal of Organic Chemistry. 1990; 55: 5444.

22. Hofmeister GE, Zhou Z, Leary JA. Journal of the American Chemical Society. 1991; 113: 5964.

23. Cancilla MT, Penn SG, Caroll JA, Lebrilla CB. Journal of the American Chemical Society. 1996; 118: 6736.

24. Asam MR, Glish GL. Journal of the American Society for Mass Spectrometry. 1997; 8: 987.

25. Fura A, Leary JA. Analytical Chemistry. 1993; 65: 2805.

26. Sible EM, Brimmer SP, Leary JA. Journal of the American Society for Mass Spectrometry. 1997; 8: 32 .

27. König S, Leary JA. Journal of the American Society for Mass Spectrometry. 1998; 9: 1125.

28. Smith G, Leary JA. International Journal of Mass Spectrometry. 1999; 193: 153.

29. Smith G, Leary JA. Journal of the American Chemical Society. 1998; 120: 13046.

30. Gaucher SP, Leary JA. Analytical Chemistry. 1998; 70: 3009.

31. Smith G, Kaffashan A, Leary JA. International Journal of Mass Spectrometry. 1999; 182/183: 299.

32. Gaucher SP, Leary JA. International Journal of Mass Spectrometry. 2000; 197: 139.

33. Desaire H, Leary JA. Analytical Chemistry. 1999; 71: 4142. 
34 Desaire H, Leary JA. International Journal of Mass Spectrometry. 2001; 209: 171.

35. Desaire H, Leary JA. Analytical Chemistry. 1999; 71: 1997.

36. Berjeaud JM, Couderc F ,Promé JC. Organic Mass Spectrometry. 1993; 28: 455.

37. Carlesso V, Fournier F, Tabet JC. European Journal of Mass Spectrometry. 2000; 6: 421.

38. Salpin JY, Boutreau L, Haldys V, Tortajada J. European Journal of Mass Spectrometry. to be published.

39 Salpin JY, Tortajada J. Advances in Mass Spectrometry. 2001; 15: 735.

40. Fura A, Leary JA. Analytical Chemistry. 1993; 65: 2805.

41 McLuckey SA. Journal of the American Society for Mass Spectrometry. 1992; 3: 599.

42 McLuckey SA, Goeringer DE. Journal of Mass Spectrometry. 1997; 32: 461.

43 Monosaccharides: their chemistry and their role in natural products; Collins P and Ferrier R. (Ed). John Wiley and Sons: Chichester 1995.

44 Whitfield DM, Stojkovski S, Sarkar B. Coordination Chemistry Reviews. 1993; 122: 171.

45 Bandwar RP, Sastry MD, Kadam, RM, Rao CP. Carbohydrate Research. 1997; 297: 333.

46 Mukhopadhyay A, Kolehmainen E, Kadam, RM, Rao CP. Carbohydrate Research. 2000; 328: 103.

47 Cerda BA, Wesdemiotis C. International Journal of Mass Spectrometry. 1999;189:189.

48 Cooks RG, Patrick JS, Kotiaho S, McLuckey SA. Mass Spectrometry Reviews. 1994; 13: 287.

49 Blanc-Muesser M, Defaye J, Foltz RL, Horton D. Organic Mass Spectrometry. 1980; 15: 317.

50 Wang G, Sha Y, Xu Z, Pan J. Analytical Chemistry. 1985; 57: 2283.

51 Suming H, Yaozu C, Longfei J, Shuman X. Organic Mass Spectrometry. 1985; 20: 719. 
52 Tu YP, Yang GY, Liu YH, Chen SN, Chen YZ. Organic Mass Spectrometry. 1991; 26: 645.

53 Deutsch J. Organic Mass Spectrometry. 1980; 15: 240.

54 Lipták M, Dinya Z, Sztaricskai J, Litkei G, Jekő, J. Organic Mass Spectrometry. 1992; 27: 1271. 


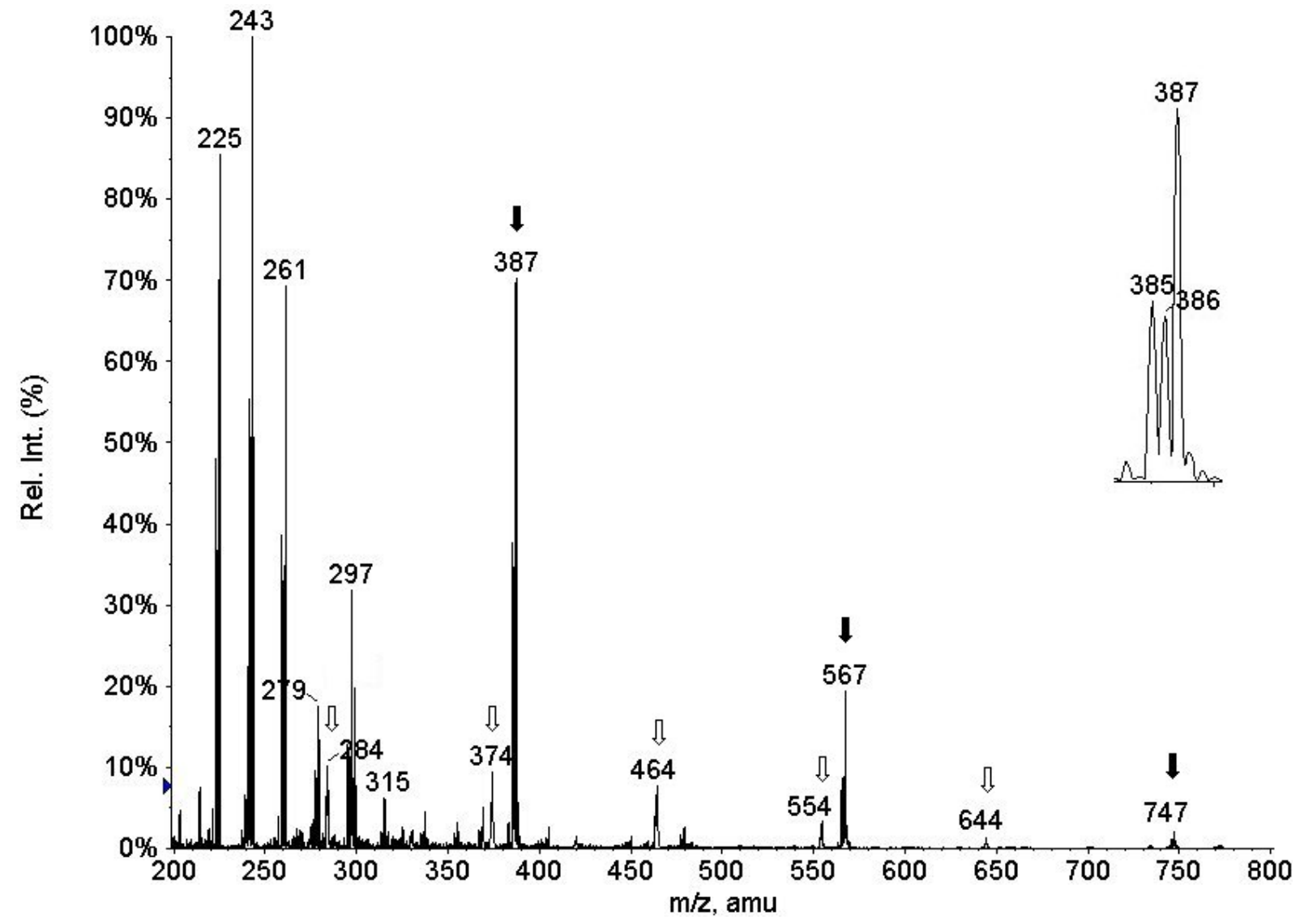

Figure 1 

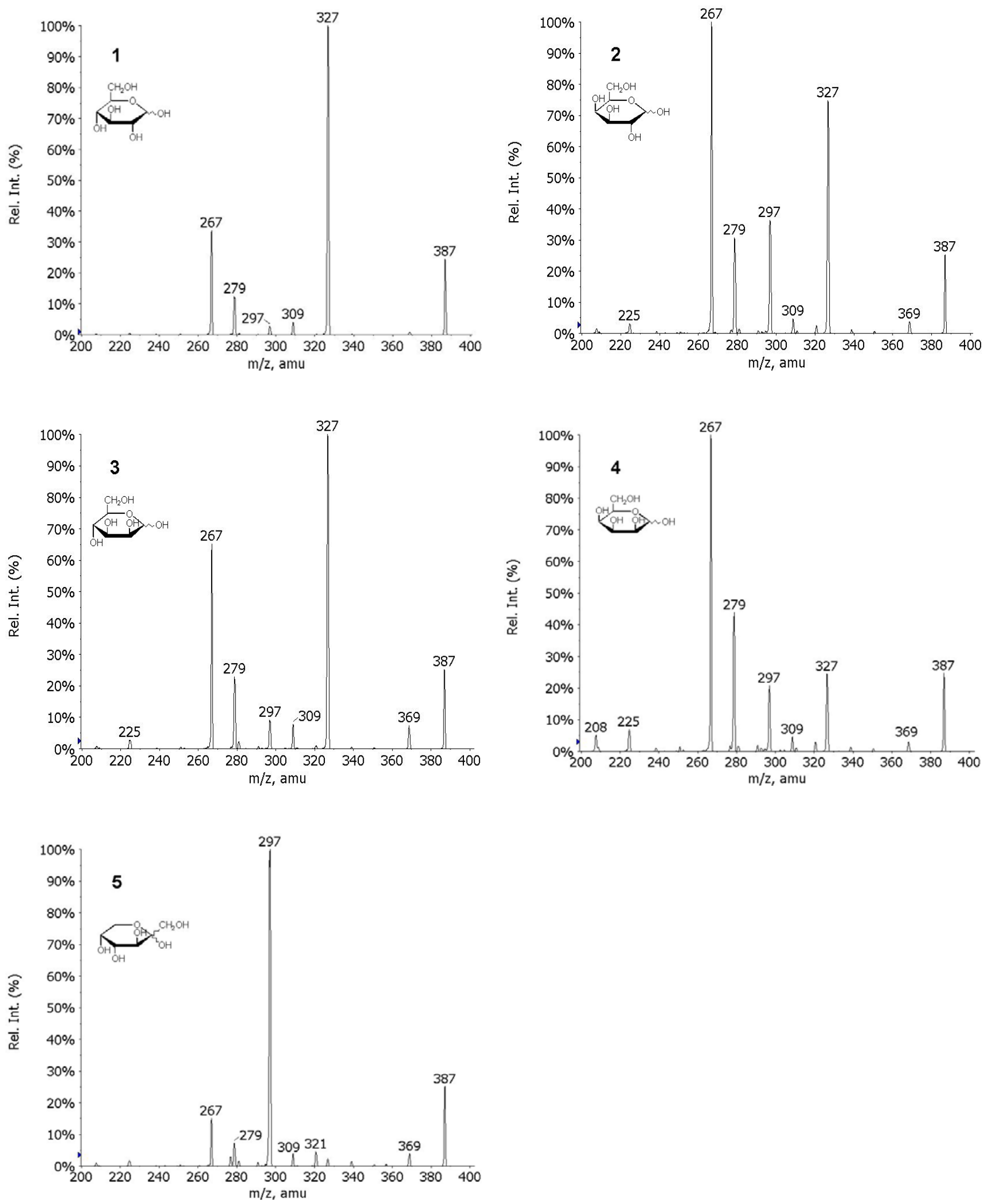

Figure 2 

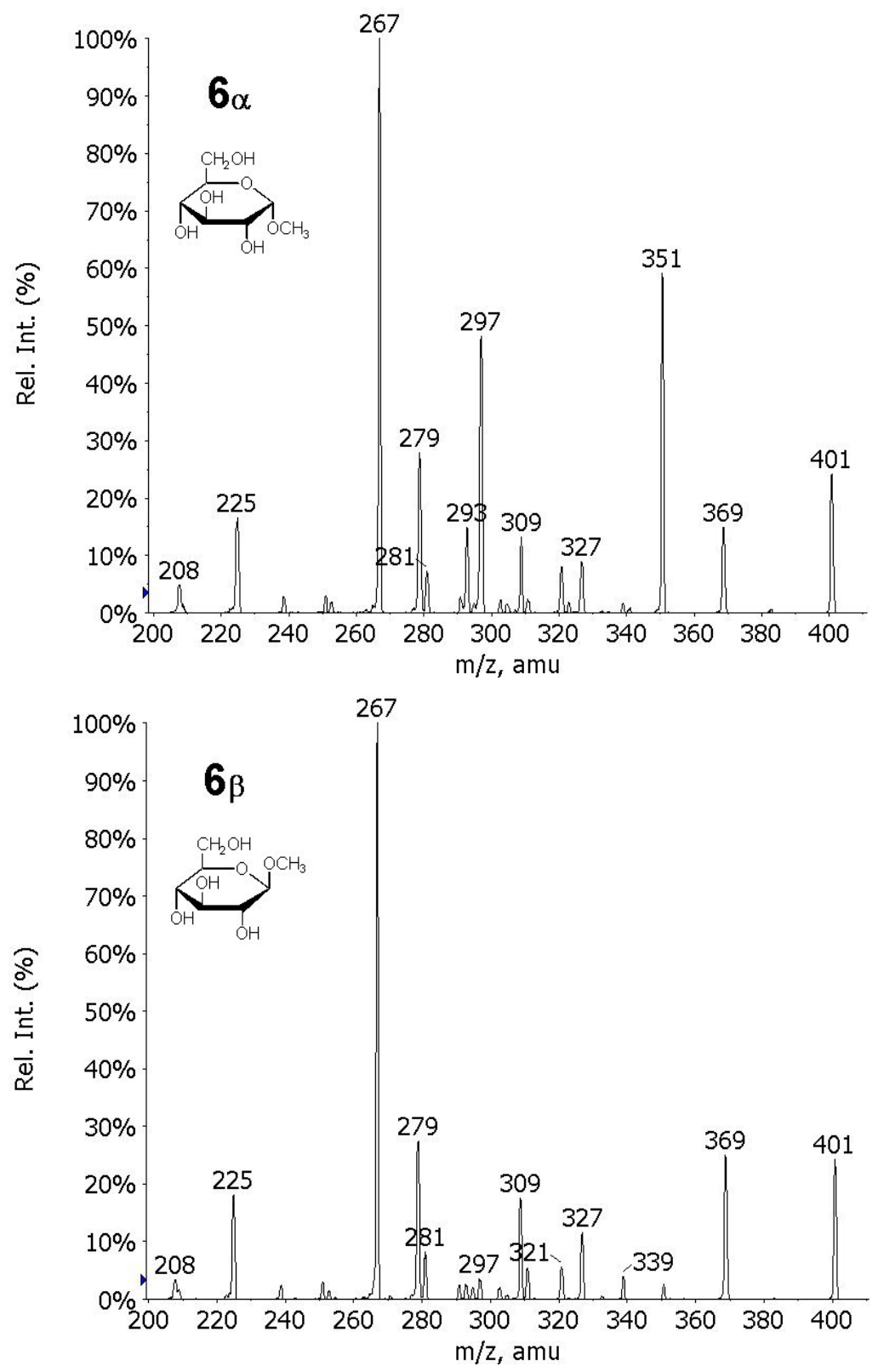

Figure 3 

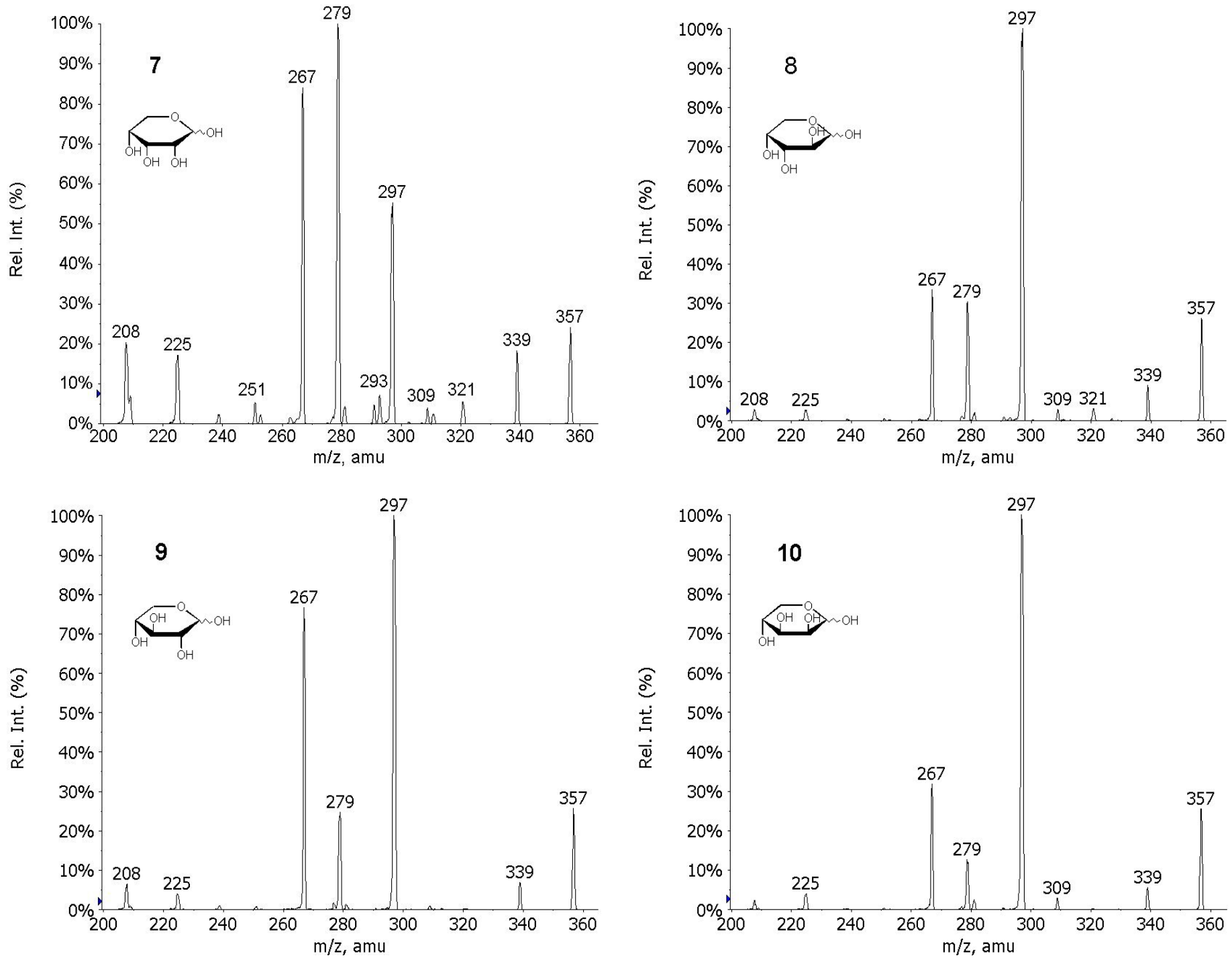

Figure 4 
Table 1. Abundance (\%) of the main fragment ions in the CID spectra of the $\left[\mathrm{Pb}(\text { hexose) }-\mathrm{H}]^{+}\right.$ions $(\mathrm{m} / \mathrm{z} 387)$ of $1-5^{\mathrm{a}}$.

\begin{tabular}{|c|c|c|c|c|c|}
\hline Structure & {$[\mathrm{Pb}(\mathbf{1})-\mathrm{H}]^{+}$} & {$[\mathrm{Pb}(\mathbf{2})-\mathrm{H}]^{+}$} & {$[\mathrm{Pb}(\mathbf{3})-\mathrm{H}]^{+}$} & {$[\mathrm{Pb}(4)-\mathrm{H}]^{+}$} & {$[\mathrm{Pb}(\mathbf{5})-\mathrm{H}]^{+}$} \\
\hline $\mathrm{E}_{\mathrm{com}}(\mathrm{eV})^{\mathrm{b}}$ & 0.9 & 1.4 & 1.3 & 1.8 & 1.1 \\
\hline $\mathrm{m} / \mathrm{z} 387$ & $24.8 \pm 1.1$ & $24.8 \pm 0.9$ & $25.5 \pm 0.8$ & $24.6 \pm 0.4$ & $24.4 \pm 1.1$ \\
\hline $\mathrm{m} / \mathrm{z} 369\left(-\mathrm{H}_{2} \mathrm{O}\right)$ & - & $4.1 \pm 0.2$ & $7.0 \pm 0.4$ & $2.9 \pm 0.2$ & $4.2 \pm 0.2$ \\
\hline $\mathrm{m} / \mathrm{z} 327\left(-\mathrm{C}_{2} \mathrm{H}_{4} \mathrm{O}_{2}\right)$ & 100 & $78.1 \pm 2.0$ & 100 & $24.1 \pm 1.3$ & - \\
\hline $\mathrm{m} / \mathrm{z} 321\left(-2 \mathrm{H}_{2} \mathrm{O},-\mathrm{CH}_{2} \mathrm{O}\right)$ & - & - & - & $2.9 \pm 0.3$ & $4.8 \pm 0.2$ \\
\hline $\mathrm{m} / \mathrm{z} 309\left(-\mathrm{C}_{2} \mathrm{H}_{4} \mathrm{O}_{2},-\mathrm{H}_{2} \mathrm{O}\right)$ & $4.2 \pm 0.3$ & $5.0 \pm 0.3$ & $8.5 \pm 0.6$ & $5.0 \pm 0.3$ & $3.6 \pm 0.1$ \\
\hline $\mathrm{m} / \mathrm{z} 297\left(-\mathrm{C}_{3} \mathrm{H}_{6} \mathrm{O}_{3}\right)$ & $2.6 \pm 0.1$ & $36.6 \pm 1.4$ & $8.9 \pm 0.3$ & $22.7 \pm 1.4$ & 100 \\
\hline $\mathrm{m} / \mathrm{z} 279\left(-\mathrm{C}_{3} \mathrm{H}_{6} \mathrm{O}_{3},-\mathrm{H}_{2} \mathrm{O}\right)$ & $12.9 \pm 0.3$ & $29.1 \pm 1.4$ & $22.7 \pm 0.3$ & $41.3 \pm 2.4$ & $6.4 \pm 0.5$ \\
\hline $\mathrm{m} / \mathrm{z} 267\left(-\mathrm{C}_{4} \mathrm{H}_{8} \mathrm{O}_{4}\right)$ & $33.9 \pm 0.8$ & 100 & $64.2 \pm 3.2$ & 100 & $15.2 \pm 1.0$ \\
\hline $\mathrm{m} / \mathrm{z} 225\left(-\mathrm{C}_{6} \mathrm{H}_{10} \mathrm{O}_{5}\right)$ & - & $2.9 \pm 0.4$ & $3.0 \pm 0.1$ & $6.4 \pm 0.7$ & - \\
\hline $\mathrm{m} / \mathrm{z} 208\left(-\mathrm{C}_{6} \mathrm{H}_{11} \mathrm{O}_{6}\right)$ & - & - & - & $3.5 \pm 0.3$ & - \\
\hline
\end{tabular}

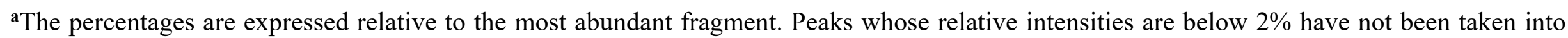
account.

${ }^{\mathrm{b}}$ Center of mass (com) collision energy. 
Table 2. Abundance (\%) of the main fragment ions in the CID spectra of the $[\mathrm{Pb} \text { (pentose)- } \mathrm{H}]^{+}$ions $(\mathrm{m} / \mathrm{z} 357)$ of $7-10^{\mathrm{a}}$.

\begin{tabular}{lcccc}
\multicolumn{1}{c}{ Structure } & {$[\mathrm{Pb}(\mathbf{7})-\mathrm{H}]^{+b}$} & {$[\mathrm{~Pb}(\mathbf{8})-\mathrm{H}]^{+}$} & {$[\mathrm{Pb}(\mathbf{9})-\mathrm{H}]^{+}$} & {$[\mathrm{Pb}(\mathbf{1 0})-\mathrm{H}]^{+}$} \\
\hline $\mathrm{E}_{\mathrm{com}}(\mathrm{eV})^{\mathrm{c}}$ & 2.0 & 1.2 & 1.6 & 1.4 \\
$\mathrm{~m} / \mathrm{z} 357$ & $24.4 \pm 0.4$ & $26.1 \pm 1.6$ & $25.3 \pm 0.5$ & $24.4 \pm 1.3$ \\
$\mathrm{~m} / \mathrm{z} 339\left(-\mathrm{H}_{2} \mathrm{O}\right)$ & $17.9 \pm 0.4$ & $8.5 \pm 0.4$ & $6.8 \pm 0.4$ & $5.8 \pm 0.3$ \\
$\mathrm{~m} / \mathrm{z} 321\left(-2 \mathrm{H}_{2} \mathrm{O}\right)$ & $5.4 \pm 0.3$ & $3.1 \pm 0.4$ & - & - \\
$\mathrm{m} / \mathrm{z} 309\left(-\mathrm{CH}_{2} \mathrm{O},-\mathrm{H}_{2} \mathrm{O}\right)$ & $3.7 \pm 0.4$ & $2.8 \pm 0.3$ & - & $2.8 \pm 0.2$ \\
$\mathrm{~m} / \mathrm{z} 297\left(-\mathrm{C}_{2} \mathrm{H}_{4} \mathrm{O}_{2}\right)$ & $55.8 \pm 0.9$ & $\mathbf{1 0 0}$ & $\mathbf{1 0 0}$ & $\mathbf{1 0 0}$ \\
$\mathrm{m} / \mathrm{z} 279\left(-\mathrm{C}_{2} \mathrm{H}_{4} \mathrm{O}_{2},-\mathrm{H}_{2} \mathrm{O}\right)$ & $\mathbf{1 0 0}$ & $29.9 \pm 0.9$ & $24.5 \pm 0.9$ & $12.5 \pm 0.7$ \\
$\mathrm{~m} / \mathrm{z} 267\left(-\mathrm{C}_{3} \mathrm{H}_{6} \mathrm{O}_{3}\right)$ & $85.2 \pm 1.7$ & $37.6 \pm 2.2$ & $75.9 \pm 2.2$ & $32.3 \pm 1.6$ \\
$\mathrm{~m} / \mathrm{z} 225\left(-\mathrm{C}_{5} \mathrm{H}_{8} \mathrm{O}_{4}\right)$ & $17.9 \pm 0.5$ & $2.9 \pm 0.2$ & $4.0 \pm 0.1$ & $4.3 \pm 0.4$ \\
$\mathrm{~m} / \mathrm{z} 208\left(-\mathrm{C}_{5} \mathrm{H}_{9} \mathrm{O}_{5}\right)$ & $20.9 \pm 1.0$ & $2.8 \pm 0.3$ & $6.9 \pm 0.5$ & - \\
\hline
\end{tabular}

${ }^{a}$ The percentages are expressed relative to the most abundant fragment. Peaks whose relative intensities are below $2 \%$ have not been taken into account.

${ }^{\mathrm{b}}$ Ions at $\mathrm{m} / \mathrm{z} 293,281$ and 251 have been omitted in this table, see spectrum.

${ }^{\mathrm{c}}$ Center of mass (com) collision energy. 